\title{
Sentinel-2 imagery usage on environmental monitoring of land use and occupation in a microwatershed in Central Brazil
}

\author{
Jean Jesus Novais ${ }^{1 *}$ (D), Marilusa Pinto Coelho Lacerda ${ }^{1}$ (D) \\ 1 Faculty of Agronomy and Veterinary Medicine, Darcy Ribeiro University Campus, University of Brasília; ICC Sul, Asa \\ Norte, Caixa Postal 4508, Brasília 70910-960, Distrito Federal, Brazil. \\ * Corresponding author: jinagron@gmail.com
}

Recebido em 13 de agosto de 2020.

Aceito em 03 de março de 2021.

Publicado em 15 de abril de 2021.

\begin{abstract}
In the last decades, sustainability concerns have increased the demand for projects and strategic plans that integrate economic and social aspects, reducing environmental impacts. In this sense, this study aims to monitor land-use adequacy in the Ribeirão Extrema microwatershed, Distrito Federal, based on cross-mapping between land-use and occupation in 2019 and agricultural aptitude map through Geographic Information Systems and Remote sensing. To this end, a hypsometric and thematic database was prepared for the region. Besides, we acquired an image from the Sentinel-2 orbital sensor of October 2019. The image was subjected to classification regarding land-use and occupation, using the MAXVER (maximum likelihood) algorithm. It was observed that $80 \%$ of use in 2019 was related to agricultural activities. Kappa index validation reached 81\% accuracy. Based on the methodology, we identified $62.33 \%$ of agricultural activities occur into its capacity; $4.33 \%$, were used above capacity, causing environmental degradation, especially in permanent preservation areas. The application of the technique was considered satisfactory because the adequacy of landuse in the studied microwatershed could be assessed in order to pursue sustainable development. Continuous analyzes can improve results.
\end{abstract}

Keywords: Geotechnology. Maximum likelihood. Agricultural aptitude. Remote sensing.

\section{Uso de imagens Sentinel-2 no monitoramento ambiental do uso e ocupação das terras em uma microbacia no Brasil-Central}

Resumo - Nas últimas décadas, a preocupação com a sustentabilidade tem aumentado a demanda por projetos e planejamentos estratégicos que integrem aspectos econômicos e sociais, reduzindo impactos ao meio ambiente. Nesse sentido, o objetivo deste estudo foi monitorar a adequação do uso do solo na microbacia do Ribeirão Extrema, Distrito Federal, a partir do mapeamento cruzado entre uso e ocupação do solo em 2019 e mapa de aptidão agrícola, por meio de Sistemas Informações Geográficas e Sensoriamento Remoto. Para tanto, foi elaborado um banco de dados planialtimétrico e temático da região. Além disso, adquirimos uma imagem do sensor orbital Sentinel-2 de outubro de 2019. A imagem foi submetida à classificação quanto ao uso e ocupação do solo, por meio do algoritmo MAXVER (máxima verossimilhança). Observou-se que 80\% do uso em 2019 estava relacionado às atividades agrícolas. A validação índice Kappa atingiu $81 \%$ de acurácia. Com base na metodologia, identificamos que $62,33 \%$ das atividades agrícolas ocorrem dentro da sua capacidade de 
uso; 4,33\%, sob uso acima da capacidade, o que causa degradação ambiental, principalmente em áreas de preservação permanente. A aplicação da técnica foi considerada satisfatória, pois a adequação do uso do solo na microbacia estudada pode ser avaliada a fim de buscar o desenvolvimento sustentável. Análises contínuas podem melhorar os resultados.

Palavras-chave: Geotecnologia. Máxima verossimilhança. Aptidão agrícola. Sensoriamento remoto.

\section{Uso de imágenes Sentinel-2 en el monitoreo ambiental del uso y ocupación del suelo en una microcuenca en el centro de Brasil}

Resumen - En las últimas décadas, la preocupación por la sostenibilidad ha incrementado la demanda de proyectos y planes estratégicos que integren aspectos económicos y sociales, reduciendo los impactos sobre el medio ambiente. En este sentido, el objetivo de este estudio fue monitorear la adecuación del uso del suelo en la microcuenca de Ribeirão Extrema, Distrito Federal, a partir del mapeo cruzado entre el uso y ocupación del suelo en 2019 y el mapa de adecuación agrícola, a través de Sistemas de Información Geográfica y Detección remota. Para ello, se elaboró una base de datos hipsométrica y temática para la región. Además, adquirimos una imagen del sensor orbital Sentinel-2 a partir de octubre de 2019. La imagen fue sometida a clasificación del uso y ocupación del suelo, utilizando el algoritmo MAXVER (máxima verosimilitud). Se observó que el $80 \%$ del uso en 2019 estuvo relacionado con actividades agrícolas. La validación del índice Kappa alcanzó un $81 \%$ de precisión. Con base en la metodología, identificamos el $62,33 \%$ de las actividades agrícolas que ocurren dentro de su capacidad de uso; $4.33 \%$, fueron utilizadas por encima de la capacidad, lo que provoca degradación ambiental, especialmente en áreas de preservación permanente. La aplicación de la técnica se consideró satisfactoria, ya que se evaluó la adecuación del uso del suelo en la microcuenca estudiada con el fin de lograr el desarrollo sostenible. Análises contínuos pueden mejorar los resultados.

Palabras-clave: Geotecnología. Máxima verosimilitud. Aptitud agrícola. Teledetección.

\section{Introduction}

In-depth knowledge about natural resources is essential for any region. In this sense, steps must be taken to exploit these resources with minimal impact on the environmental, social, and economic aspects. Food security and environmental quality maintenance are just two reasons why humanity should be concerned about preserving natural resources to sustain life on Earth (United Nations 1987).

However, unavailability or low quality of information about these resources leads to inappropriate land-use due, for instance, difficulties of having cartographic material arise from the complexity of data acquisition whose classical techniques incur high demands of time and specialized staff and, consequently, a significant increase in financial costs (Jesen 2009).

In recent years, the concern about sustainable development has increased the demand for projects, plans, and strategies that integrate the different economic and social agents, which reduce the impacts on the environment. The United Nations (1987) defined sustainability as developing socioeconomic while preserving the environment and having a minimal impact on future generations. Hence, geotechnologies assume a prominent position regarding the development and 
planning of environmental studies, justifying its application in different areas of Science, including agricultural and environmental issues (Sano et al. 2019).

Data from orbital sensors portray spectral responses of targets on the Earth's surface (Jensen 2009). Moreover, land-use and occupation can assist the socioeconomic and environmental planning of a given region (Novais et al. 2016). Remote Sensing (SR) technologies associated with Geographic Information Systems (GIS) have provided identification of potentially productive lands or those most susceptible to environmental degradation (Radoux et al. 2016; Borràs et al. 2017; Mylona et al. 2018; Kobayashi et al. 2019; Nguyen et al. 2020; Leopoldo et al. 2020).

According to Wang et al. (2018), automated image classification techniques allow elaborating thematic maps efficiently. The features arranged on the surface are generalized according to their standard parameters, attributing each pixel group to a particular predefined category using classification algorithms (Lago et al. 2012).

Regarding environmental studies, the Sentinel-2 (S-2) multispectral sensor provides a high capacity to discriminate targets on Earth's surface. The spectral bands' arrangement stands out the most of interest materials. For instance, from colorful composition RGB 8/4/3 and 4/8/3, bare soil and vegetation features are highlighted, allowing an analysis more precise of their spectral responses from orbital images (ESA 2015).

The present study objective was to monitor land use's adequacy in the Ribeirão Extrema microwatershed, Brazilian Federal District (FD), based on the cross-mapping between land-use and occupation in 2019 map and agricultural aptitude map, through Geographic Information Systems and Remote Sensing.

We based the establishment of different land-use and occupation classes and agricultural aptitude of lands considering some physiographic variables. Such factors determine support capacity for various types of agricultural exploitation presented by lands appointing locals, which sustainable practices could be adopted for conservationist management of natural resources.

\section{Material and Methods}

\section{Characterization of the study area}

The great hydrographic basin of Rio São Francisco in Central Brazil has the Rio Preto watershed comprising the subunit Ribeirão Extrema (RE) creek (Figure 1). It has over 25 thousand hectares, located on the Eastern FD, into the UTM coordinates zone 23S: 225,547 m,

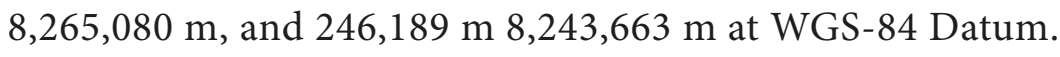


Figure 1. Location of Ribeirão Extrema microwatershed, FD, with S-2 Image in false color from band math. AR. Administrative Region.

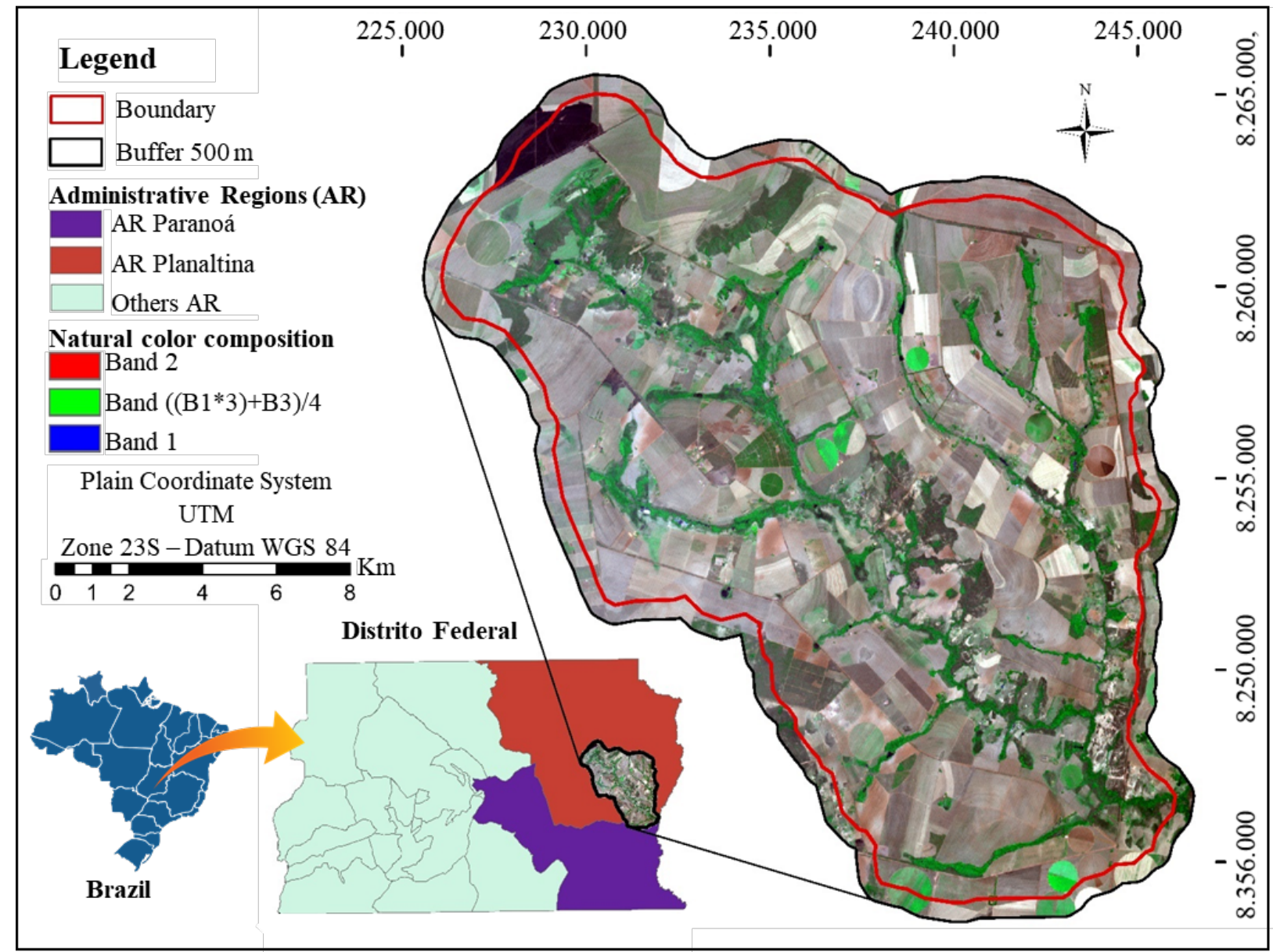

The region has a Tropical Aw, Tropical Climate of Altitude, Cwa, and Cwb contained in the Köppen climate classification (Castro and Lima 2020). The average annual rainfall is about 1,300 $\mathrm{mm}$, irregularly distributed throughout the year. We obtained an image scene from the multispectral sensor of the S-2 satellite, dated October 10, 2019 (Figure 1).

It is within the biome Cerrado (tropical savannah) domain, which presents distinct phytophysiognomies from undergrowth (field Cerrado) until dense vegetation (Cerradão) (Sano et al. 2019). This picture shows the intense anthropic activity over non-renewable natural resources, as soil and water, regarding land-use in RE.

\section{Acquisition and digital processing Sentinel-2 Image}

Multi-Spectral Instrument sensor (MSI) from the European Space Agency boarding S-2 orbital platform has a heliosynchronous orbit at $786 \mathrm{~km}$ from Earth surface passing at equator every five days (from two satellites S-2 A and B of constellation Copernicus). It has 13 bands (Table 1) in the VNIR and SWIR range (ESA 2015). 
Table 1. Bands characteristic of Sentinel-2 MSI sensor.

\begin{tabular}{ccccc}
\hline Number & Sentinel-2 Bands & $\begin{array}{c}\text { Central Wavelength } \\
(\mu \mathrm{m})\end{array}$ & $\begin{array}{c}\text { Spatial } \\
\text { Resolution }(\mathrm{m})\end{array}$ & $\begin{array}{c}\text { Used in this } \\
\text { work }\end{array}$ \\
\hline 1 & Name & 0.443 & 60 & No \\
2 & Coastal Aerosol & 0.490 & 10 & Yes \\
3 & Blue & 0.560 & 10 & Yes \\
4 & Green & 0.665 & 10 & Yes \\
5 & Vegetation Red Edge 1 & 0.705 & 20 & Yes \\
6 & Vegetation Red Edge 2 & 0.740 & 20 & Yes \\
7 & Vegetation Red Edge 3 & 0.783 & 20 & Yes \\
8 & NIR & 0.842 & 10 & Yes \\
$8 \mathrm{~A}$ & NIR Narrow & 0.865 & 20 & Yes \\
9 & Water Vapor & 0.945 & 60 & No \\
10 & SWIR - Cirrus & 1.375 & 60 & No \\
11 & SWIR 1 & 1.610 & 20 & Yes \\
12 & SWIR 2 & 2.190 & 20 & Yes \\
\hline
\end{tabular}

Source: Adapted from ESA (2015)

We got an orbital image S-2 with an L1B processing level, which was applied geometrical corrections on georeferencing of the image based on vectorial data hydrography and local elevation extracted from the SICAD data basis (Federal District 1991). We applied a spectral corrections algorithm that uses empirical values to transform radiance pixels into a reflectance (TOA) factor at the top of the atmosphere (ESA 2015).

Therefore, SNAP program (ESA 2015) version 5,0 aided with the digital image treatment, which performed the following processing steps: 1 - Geometric correction on S-2 image in register function, using the first-degree polynomial model and resampling from nearest neighborhood prediction method; 2 - Checking georeferencing from FD hydrographic map (Federal District 1991) and reprojection for UTM zone 23 south at the plane coordinate system at WGS-84 Datum.

Following, the third step consisted in Radiometric and atmospheric correction applied to each of the image bands using the Sen2cor module into SNAP. After, we processed the program's image dedicated to this purpose, ENVI v. 5.3 (EXELIS Inc. 2018), to improve visual quality and facilitate the visualization of regions of interest (ROI).

\section{Geoprocessing}

Regarding the generation of a digital database, it was taking account the planialtimetric charts from FD, on 1: 10,000 scale, prepared by the Companhia de Desenvolvimento do Planalto - CODEPLAN loaded initially by ArcGis ${ }^{\mathrm{TM}}$ 10.3.1 program (ESRI 2015), thematic maps of soils 
and agricultural aptitude lands (Freitas et al. 1978) and geomorphological map of FD, available in Castro and Lima (2020).

We delimited the RE area generating a polygonal vector file from contour and hydrography lines extracted from FD's planialtimetric maps (Federal District 1991). Beyond the study area boundary, a $100 \mathrm{~m}$ buffer establishing a spare area to facilitate operations on matrix files and avoid misprocessing in the image edges.

After, we elaborated a Digital Terrain Model (DTM) of microwatershed from vector files extracted from the FD planialtimetric base of elevation points cloud, hydrography, and contour lines equidistant $5 \mathrm{~m}$. We also generated a hypsometric class map (altitudes) and a slope class map from DTM (Federal District 1991).

All thematic maps were duly clipped from the studied area's boundary buffer, establishing the soil, agricultural aptitude, and geomorphology maps of the RE. According to the Land-use Aptitude Classification System in Brazil proposed by Ramalho Filho and Beek (1995), RE's agricultural aptitude was spatialized, which subdivided the lands into categories according to edaphic, climatic, and technological, among others, as shown in table 2.

Table 2. Symbology corresponding to classes of agricultural aptitude of land.

\begin{tabular}{cccccccc}
\hline & \multicolumn{7}{c}{ Type of Use } \\
\cline { 2 - 8 } Agricultural aptitude classes & \multicolumn{1}{c}{ Crop } & & Planted pasture & Reforestation & Natural pasture \\
\cline { 2 - 8 } & \multicolumn{1}{c}{ Management Level } \\
\cline { 2 - 8 } & A & B & C & B & B & B \\
\hline GOOD & A & B & C & P & S & N \\
REGULAR & A & b & C & P & s & $\mathrm{n}$ \\
RESTRICT & (a) & (b) & (c) & $(\mathrm{p})$ & $(\mathrm{s})$ & $(\mathrm{n})$ \\
INAPT & - & - & - & - & - & - \\
\hline
\end{tabular}

Source: Adapted from Ramalho Filho and Beek (1995).

\section{Classification of land-use in the Ribeirão Extrema microwatershed}

In ENVI 5.3 program, we clipped the image by masking the vector generated in the microwatershed boundary. After visual analysis, the following classes of land-use and occupation were established as 1 - Agriculture (A): Agricultural activities of the annual or perennial cycle; 2 Bare Soil (BS): areas intended for agriculture without vegetation cover; 3 - Straw (S): a reserved area for agriculture with decomposing vegetation cover.

The fourth class was called Mata de Galeria (MG): Dense native vegetation margins of a creek, vegetation similar to riparian forests; 5 - Cerrado (C): Native vegetation consisting of Savannah; 6 - Reforestation (R): Areas characterized by standardized geometry formed generally by eucalyptus and pinus species; 7 - Water Bodies (WB): characterized by lakes and small dams. Thus, we proceed with collecting ROI into the image. 
Afterward, we applied the MAXVER algorithm (maximum likelihood) on images in which approximately 300 pixels (pictures elements) were sampled for each class of land-use and occupation to perform the supervised classification. After achieving the desired efficiency in the classes' individualization, the automated classification constituted the map of land-use and occupation from RE microwatershed in a matrix file. The matrix file was converted to a vector file and exported in archives shapefile (.shp) for GIS processing.

The classification was evaluated by the Kappa index, calculated from the confusion matrix in 350 points selected randomly into the boundary of the microwatershed through ENVI 5.3. According to Congalton and Green (2013), the Kappa Index (Equation 1) is a measure of agreement. This technique provides an idea of how far the observations depart from those expected. As a result of chance, it indicates how legitimate the interpretations are. It is being used as a measure of agreement between the map and the reference adopted for this work's accuracy estimative.

$$
K=\frac{\left[n \times \sum_{i=1}^{r} x i j-\sum_{i=1}^{r}\left(x_{i} \times x_{j}\right)\right]}{\left[n^{2}-\sum_{i=1}^{r}\left(x_{i} \times x_{j}\right)\right]}
$$

Equation 1

Where $K$ is the Kappa Accuracy Index, $r$ is the number of lines in the matrix, $x$ is the number of observations in a row $(i)$, and column $(j)$, and $n$ is the total number of observations. It is possible assessing the classification quality through Kappa Index. According to Congalton and Green (2013), the Kappa Quality Index values vary between: 0.81 to 1.00, Excellent; 0.61 to 0.80 , Very good; 0.41 to 0.60 Good; 0.21 to 0.40 , Reasonable; 0.01 to $0.20 \mathrm{Bad}$ and 0.00 , Unsatisfactory.

To assess the adequacy of agricultural use of water in microwatershed studied, the land-use and occupation maps and the agricultural aptitude and permanent preservation area (APP) maps were cross-checked, both in a matrix format, using the raster calculation tool in ArcGis 10.3.1 (ESRI 2015). As a result, we exported the attributes table to MS Excel to perform another calc.

Four classes of adequacy were established through the use assessment concerning agricultural aptitude map: preservation of natural cover, agricultural below the potential land-use, and agricultural above the agricultural land-use potential and adequate land-use. The percentage areas of classes of land-use aptitude were quantified by attribute math function in ArcGis 10.3.1.

\section{Results and Discussion}

\section{Physiographic characterization of the study area}

The area studied is characterized by Oxisoils (Latossolo Vermelho) predominance covering $76 \%$ of the area (Figure 2a) under agricultural aptitude 2 (b)c level, corresponding to land with a regular aptitude for tillage at management level $\mathrm{C}$, restricted in management level $\mathrm{B}$ and unapt at management level A (Figure 2b). The altitude varied from 850 to $1200 \mathrm{~m}$ (Figure 2c). It is worth mentioning that slope classes are important conditioning factors for the agricultural aptitude of land, where restrictive areas of use can occur in more accentuated slopes (Figure 2d). 
Figure 2. Map of (a) soil classes Santos et al. (2018); (b) aptitude classes Ramalho and Beek (1985); (c) hypsometric classes with Permanent Preservation Areas and (d) slope classes.

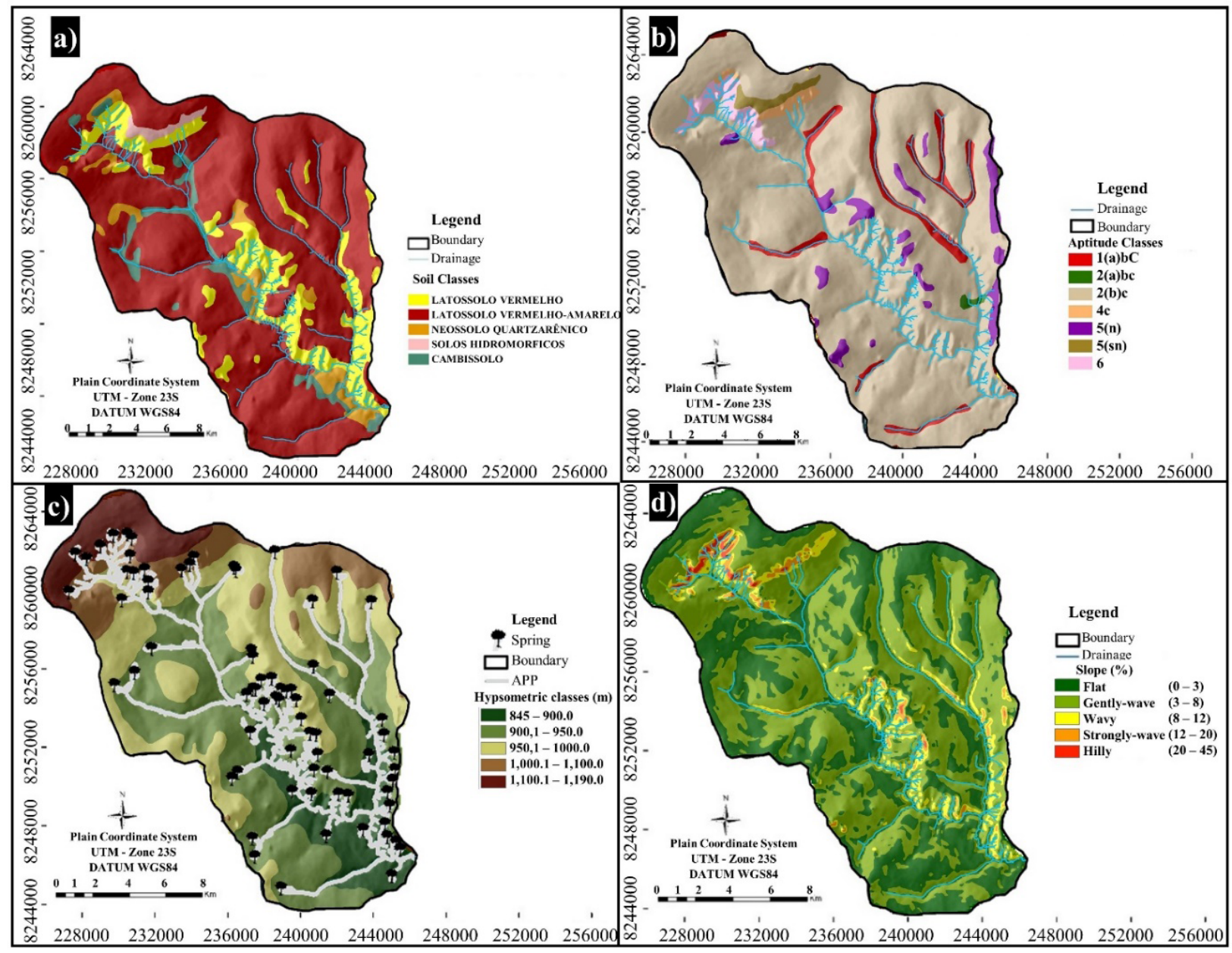

\section{Classification of land-use in Ribeirão Extrema microwatershed}

In this study, the MAXVER algorithm modeled the ROIs extracted from the S-2 image. Such a method considers a weighting of distances between digital media levels from classes using statistical parameters. The "pixel by pixel" multispectral classification technique considers area in the attribute space around a training set. This class has a parallelepiped shape defined by maximum and minimum digital numbers for the training set (Nguyen et al. 2020).

The land-use and occupation map generation was considered satisfactory, achieving against all targets on the S-2 image. Polygonal patterns can be visualized in figure 3, and they represent anthropic activity. Nonetheless, there were misshapen patterns in the classification result from the native vegetation remaining on the higher slopes and along the stream.

The bare soil showed features of paved and unpaved roads proving a similar spectral behavior between these targets. Novais et al. (2016), Radoux et al. (2016), Wang et al. (2018), Almeida et al. (2020), and Nguyen et al. (2020) also stated the misclassification most common are related to the similarity of spectral signatures or ROI non-representative gathering.

Still, in Figure 3, it is possible to observe the predominance of anthropic activities related to agriculture, reforestation, bare soil, and Straw (mulch over the soil), adding up to about $80 \%$ of 
the total area of the microwatershed. On the other hand, the remaining $20 \%$ of natural coverage represented by the Mata de Galeria and Cerrado (Savannah) classes.

Figure 3. Land-use and occupation of Ribeirão Extrema microwatershed in 2019.

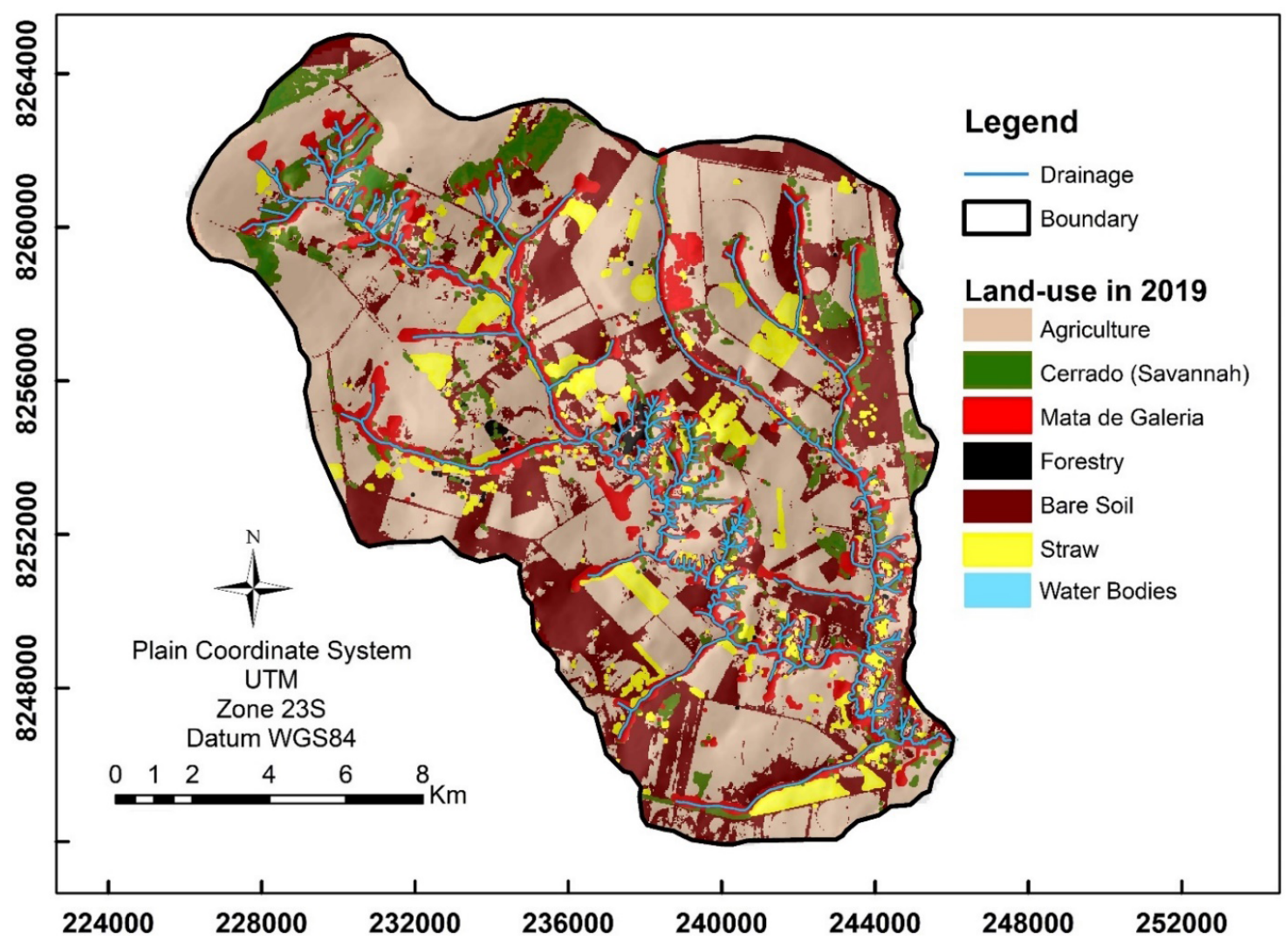

It is stated in the law that $20 \%$ of natural vegetation covering must be preserved in the Cerrado biome according to the Brazilian Code of Forest (Brasil 2012). Besides this, the native vegetation has been largely suppressed. Water bodies (lakes and small dams) reached less than $1 \%$ of the total area, as displayed in table 3.

Table 3. Quantification land-use and occupation classes in study area in 2019. A = Agriculture; $C=$ Cerrado; $\mathrm{MG}=$ Mata Galeria; $\mathrm{BS}=$ Bare Soil; $\mathrm{R}=$ Reforestation; $\mathrm{S}=$ straw; WB = Water bodies .

\begin{tabular}{cccc}
\hline Land-use and occupation & Sigle & Area (ha) & Area \% \\
\hline Agriculture & A & $12.781,74$ & 50,38 \\
Cerrado (Savannah) & C & $3.135,81$ & 12,36 \\
Mata de Galeria & MT & $2.095,62$ & 8,26 \\
Bare Soil & BS & $6.203,13$ & 24,45 \\
Reforestation & R & 114,17 & 0,45 \\
Straw & S & $1.017,36$ & 4,01 \\
Water Bodies & WB & 22.83 & 0,09 \\
\hline TOTAL & & $25.370,66$ & 100,00 \\
\hline
\end{tabular}


There were difficulties in separating the vegetation classes. Kobayashi et al. (2019) considered such confusion as expected due to spectral resemblance between these targets (Figure 4). Similar results were related by Lago et al. (2012) when they assessed land-use adequacy in this region in 2011. Novais et al. (2016) classified land-use using MAXVER on Landsat imagery, and they obtained satisfactory results for a watershed in the Northwest of Brazil.

Figure 4. Reflectance spectral of Sentinel-2 pixels: a) wavelength and b) S-2 MSI sensor bands.

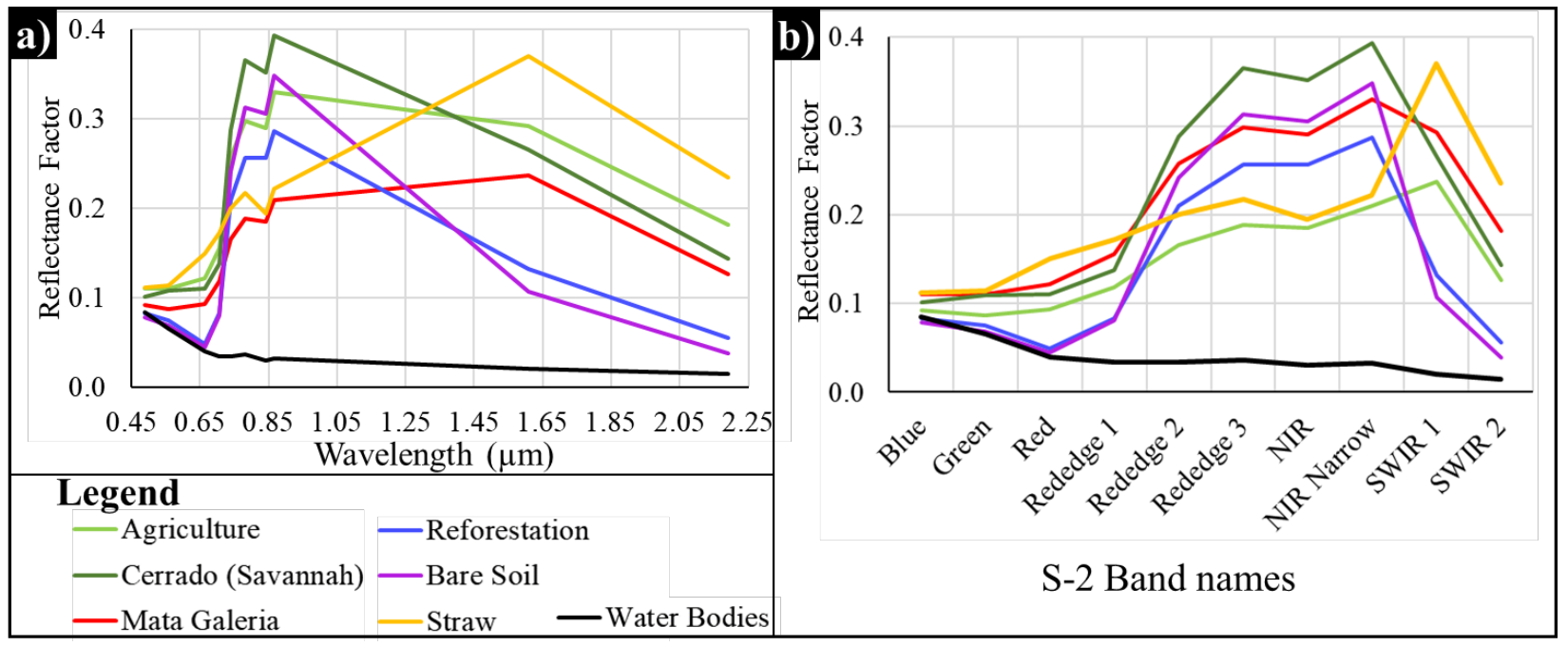

However, Novais et al. (2016) related confusion of model regarding discrimination of Agriculture and Native Vegetation. Nevertheless, Borràs et al. (2017) produced maps of land-use with diversified crops for two agricultural areas with S-2 images. Their results showed that spatial and radiometric Resolution of S-2 missions improved the classification results significantly compared to other operational sensors, besides a short legacy (this sensor began in 2015) (ESA 2015).

\section{Validation land-use classification in Ribeirão Extrema microwatershed}

Among 350 points sampled, 283 corresponded to field truth, of which most hits were included in Agriculture class. On the other hand, the control points related to Cerrado, Reforestation, Bare Soil, and Straw presented more discrepancies regarding reality in the field. As mentioned above, this fact can be justified by the similarity in spectral behavior in these aims, which generates conflicts during the classification process.

The overall accuracy corresponds to descriptive statistics for map validation. Dividing the sum of the main diagonal (Table 5 , highlighted in gray) by the total number of sampled points (Table 4 , number in bold) $(283 / 350=81 \%)$, we obtain this value. Thus, the number of correct points in a determined category was divided by the total sampled in each row or column of the confusion matrix to obtain classification accuracy (Congalton and Green 2013).

At the column level (producer's accuracy), these operations' result indicates the probability of a reference point for the class has been classified correctly. This fact denotes an omission error measure (Table 5). However, if the total number of correct answers in a category is divided by 
the total number of points classified in that category, this result is a measure of commission error (user accuracy or reliability). It indicates a point classified on the map image or represents this field truth category (Congalton and Green 2013).

Table 4 exhibited descriptive statistics of global accuracy, reaching the proportion of $80.86 \%$ accuracy (Kappa), which is considered as "Excellent," as stated in Congalton and Green (2013). The agriculture class achieved the highest probability of agreement in classification, both producer's accuracy (85.29\%) and the user's accuracy (86.57\%).

There was more confusion between bare soil and agriculture classes, which had 10 pixels misclassified because the spectral mixture in bare soil and agricultural areas was under different crop vegetative stages. Water bodies class had the lowest percentages of the accuracy of producer and user (50\%) owing a few pixels selected at the study area so that the 2 points presented one miss exact accuracy parameter.

Table 4. Confusion matrix Classification performed. $\mathrm{A}=$ Agriculture; $\mathrm{C}=$ Cerrado; $\mathrm{MG}=$ Mata de Galeria; $\mathrm{BS}=$ Bare Soil; $\mathrm{R}=$ Reforestation; $\mathrm{S}=$ straw; $\mathrm{WB}=$ Water bodies .

\begin{tabular}{|c|c|c|c|c|c|c|c|c|c|c|}
\hline \multirow{11}{*}{$\begin{array}{l}\text { Class types } \\
\text { determined } \\
\text { from the } \\
\text { classified map }\end{array}$} & & \multicolumn{7}{|c|}{$\begin{array}{l}\text { Class types determined from } \\
\text { reference source }\end{array}$} & \multirow[b]{2}{*}{ Total } & \multirow{2}{*}{$\begin{array}{l}\text { User's } \\
\text { accuracy }\end{array}$} \\
\hline & & A & $\mathrm{C}$ & MG & BS & $\mathrm{F}$ & S & WB & & \\
\hline & A & 116 & 3 & 1 & 2 & 10 & 2 & 0 & 134 & 86.57 \\
\hline & C & 9 & 43 & 1 & 1 & 2 & 0 & 0 & 56 & 76.79 \\
\hline & MG & 1 & 4 & 25 & 2 & 0 & 0 & 1 & 33 & 75.76 \\
\hline & $\mathrm{BE}$ & 0 & 0 & 4 & 7 & 0 & 0 & 0 & 11 & 63.64 \\
\hline & $\mathrm{F}$ & 6 & 4 & 0 & 0 & 72 & 3 & 0 & 85 & 84.71 \\
\hline & $S$ & 4 & 1 & 1 & 0 & 4 & 19 & 0 & 29 & 65.52 \\
\hline & WB & 0 & 0 & 1 & 0 & 0 & 0 & 1 & 2 & 50.00 \\
\hline & Total & 136 & 55 & 33 & 12 & 88 & 24 & 2 & 350 & 71.85 \\
\hline & $\begin{array}{l}\text { Producer's } \\
\text { accuracy }\end{array}$ & 85.29 & 78.18 & 75.76 & 58.33 & 81.82 & 79.17 & 50.00 & 72.65 & 80.86 \\
\hline
\end{tabular}

\section{Adequacy of land-use and occupation of the study area in 2019}

The crossing of the land-use and occupation map of 2019 generated in this work (figure 4) with the agricultural aptitude map of land (Freitas et al. 1978) (Figure 2b) resulted in a map of the adequacy of land-use and occupation in the study area (Figure 5) associated with a table containing percentage values of overlapping classes confronted (Tabela 6).

It is possible to observe that $20.62 \%$ of the area has preserved natural coverage according to the level of aptitude (Figure 5). Withal, 4.6\% referring to management level 6, were overlapped as Agriculture (A). These areas are destined for environmental reserves. Therefore, according to Ramalho Filho and Beek (1995), they are inapt for agricultural activities. They constituted an inadequate land-use above the potential of land aptitude. Such restrictions are associated mainly with wavy to steep slopes hindering agricultural management and mechanization. 
It was also observed that lands below their agricultural potential (12.63\% of the study area) are being used under class $2(\mathrm{ab}) \mathrm{c}(5.46 \%)$. They are inapt areas for crops however were occupied by Cerrado and Mata de Galeria currently. Furthermore, suppose an area was considered below agricultural potential. It does not mean that its land-use should be intensified, only that the land has the potential for more intensive use, but it presents importance to conservationist use, which is essential for environmental sustainability in the microwatershed.

However, $4.33 \%$ of the study area showed land-use above the potential regarding the agricultural aptitude of land, with the main contribution of $1.64 \%$ from the Agriculture class and $1.47 \%$ of Bare Soil in the agricultural aptitude class 5 (n). Inadequacy for land use of these areas is mainly due to agriculture and pastures planted in areas with agricultural aptitude or natural forests, generating a highly intensive use on lands corresponding to these aptitude classes, promoting environmental degradation.

Several authors have used this methodology, including Lago et al. (2012), who showed satisfactory results in assessing land-use and occupation adequacy in the regions studied. Souza et al. (2015) also studied land-use adequacy in a watershed in São Paulo State, Brazil, and had identified pastures and fields occupying places with overuse could be playing the role of primary vegetation in these areas. They stated that most critical areas occupied by temporary and annual crops should be reassessed about their use.

Figure 5. Map of the adequacy of land-use and occupation in the study area in 2019.

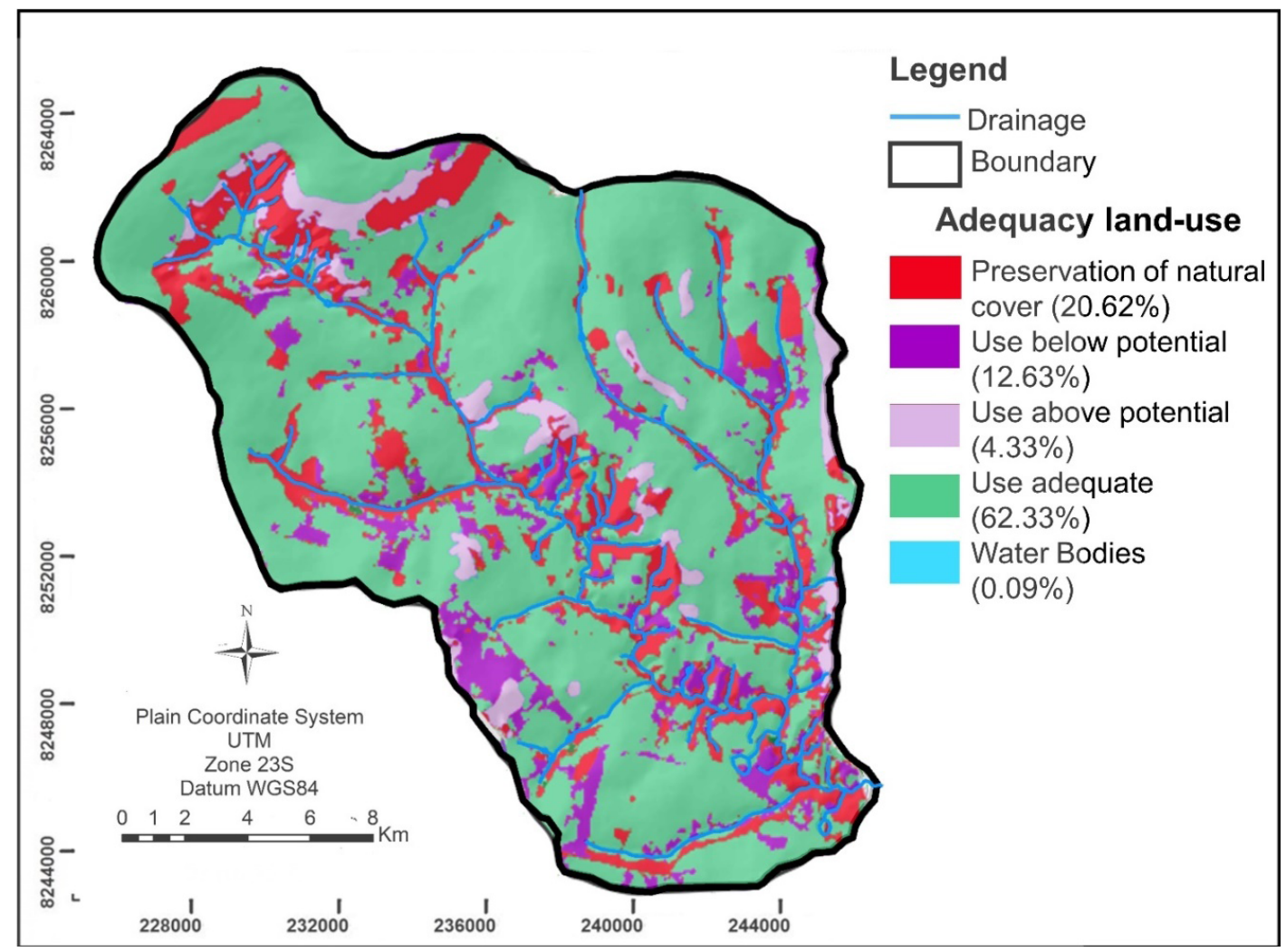

As shown in Figure 6, the local area is under anthropic pressure with outstanding suppression of native vegetation including the preservation permanent areas and Cerrado classes, contrasting with the principles of sustainability since this causes environmental degradation. According to 
Silva et al. (2017), the vegetation suppression associated with inadequate management watersheds can imply changing chemical, physical and biological attributes of soils, water resources, and conditions of balanced ecosystems.

Figure 6. Picture from study area showing some land-use classes. $A=$ Agriculture; $C=$ Cerrado; $M G=$ Mata de Galeria; BS = Bare Soil; R = Reforestation; $\mathrm{S}$ = straw.

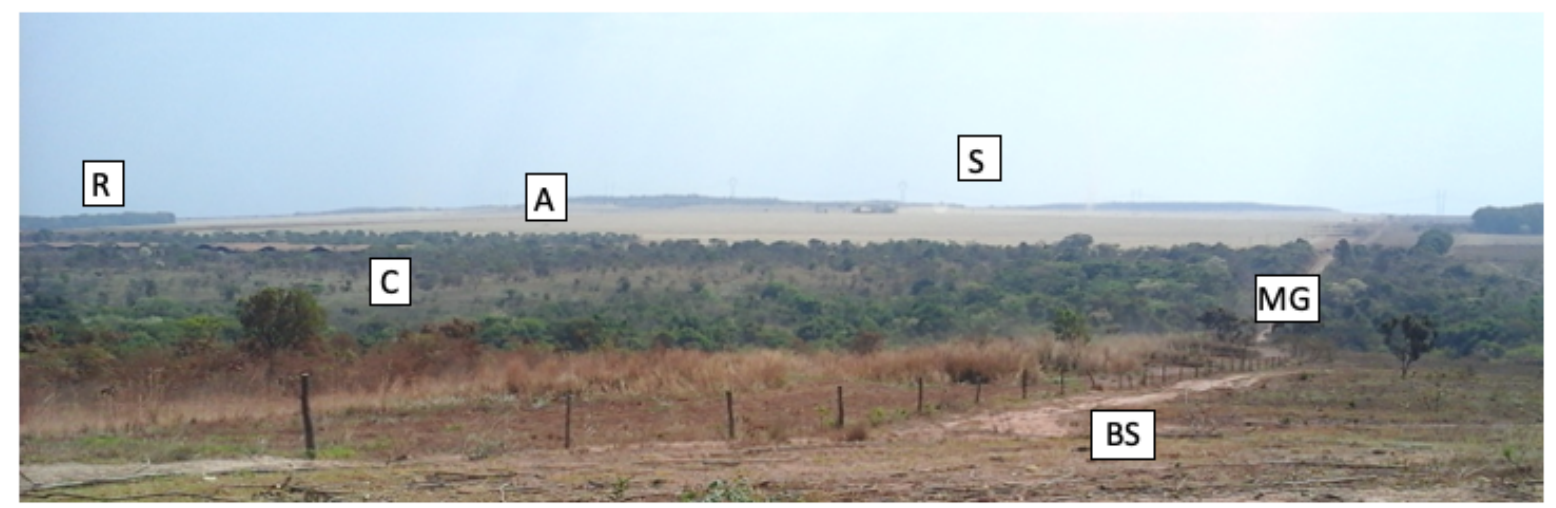

The data assessing obtained by cross-tabulation (Table 5) showed $62.33 \%$ of studied lands were classified as areas suitable for agricultural use (Agriculture, Bare Soil and Straw), with the main contribution in aptitude class 2 (a) bc under land-use from $46.06 \%$ of Agriculture and $19.80 \%$ of Bare Soil. The main limiting factor of agricultural land-use in the Cerrado region is the deficiency of fertility, which can be solved with soil correction and fertilization (Ramalho Filho and Beek 1995).

On the other hand, Wang et al. (2018) assessed S-2 MSI spectral band reflectance for estimating fractional vegetation cover, and they concluded that this sensor is suitable for spectral classification purpose. Leopoldo et al. (2020) evaluated environmental vulnerability based on the analysis of vegetation cover and alteration of the landscape resulting from management forms in a conservation unit in central Brazil. They concluded that remote sensing represents an essential tool for environmental management.

Table 5. Quantification adequacy of land-use, in 2019. A = Agriculture; $C=$ Cerrado; $M G=$ Mata de Galeria; $\mathrm{BS}=$ Bare Soil; $\mathrm{R}=$ Reforestation; $\mathrm{S}=$ straw; $\mathrm{WB}=$ Water bodies.

\begin{tabular}{ccccccccc}
\hline \multirow{2}{*}{$\begin{array}{c}\text { Agricultural } \\
\text { Aptitude }\end{array}$} & \multicolumn{7}{c}{ Land-use and occupation in 2019 } \\
\cline { 2 - 9 } & A & C & MG & BS & R & P & CH & Total \% \\
\hline 1(a)bC & 1.67 & 0.43 & 2.07 & 1.08 & & 0.18 & 0.04 & 5.47 \\
$2(\mathrm{a}) \mathrm{bc}$ & 46.06 & 10.66 & 5.46 & 19.80 & 0.45 & 3.60 & 0.05 & 86.08 \\
$2(\mathrm{~b}) \mathrm{c}$ & 0.01 & 0.18 & 0.12 & 0.01 & & & & 0.32 \\
$4 \mathrm{p}$ & 0.18 & 0.19 & 0.14 & 0.46 & & & & 0.97 \\
$5(\mathrm{n})$ & 1.64 & 0.49 & 0.15 & 1.47 & & 0.22 & & 3.97 \\
$5(\mathrm{sn})$ & 0.58 & 0.20 & & 0.19 & & & & 0.97 \\
6 & 0.24 & 0.21 & 0.32 & 1.44 & & 0.01 & & 2.22 \\
Total \% & 50.38 & 12.36 & 8.26 & 24.45 & 0.45 & 4.01 & 0.09 & 100.00 \\
\hline
\end{tabular}


The analysis shows that areas defined as APPs coincide with class 4 - Mata de Galeria in 98.36\%, which proves the methodology adopted and contributes to assessing land-use adequacy. It should be noted that remote sensing monitoring is a useful technique for planning and making decisions that involve socioeconomic and environmental aspects in the sense of seeking sustainability in terms of the exploitation of natural resources.

\section{Sustainable land-use and occupation assessing}

Descriptive data on land-use and occupation were successfully presented, and it could be utilized for several proposes as public policies development, urban planning in regional domains, or local scales as a microwatershed. Most of the studies approach methodologies applying geotechnologies for resource investigations. However, these authors did not necessarily discuss their implicatures regarding sustainability (Lago et al. 2012; Novais et al. 2016; Borràs et al. 2017; Freitas et al. 2017; Almeida et al. 2020) and others.

Leopoldo et al. (2020), nonetheless, have performed a mapping of the environmental vulnerability in the Nascentes do Rio Parnaíba National Park. Thus, they stated there is a direct correlation between the index of environmental vulnerability and the index and quality of vegetation cover, even though significant variations occurring with the other variables, such as pedomorphogeological conditions, emphasizing, therefore, attention still more careful compliance with the protection of some areas.

Similarly, the present study brought a map showing areas where sustainable interventions could be adopted for environmental preservation and observing the economic and social aspects. Concept sustainability presented at the United Nations Brundtland Commission panel in 1987 “ meeting the needs of the present without compromising the ability of future generations to meet their own needs " (United Nations 1987).

Nowadays, countries widely use this concept to make decisions, and it fits this article's objectives, considering the exploration or conservation areas adding factors such as social and economic relationships. Finally, this study was to show a method used for identifying these areas being preserved or above or below its potential therefore may serve as guidance to adopt sustainable policies, e.g.

\section{Conclusion}

The assessment of aptitude under land-use and occupation in Ribeirão Extrema microwatershed showed that $62.33 \%$ of the study area was under suitable use in 2019 . However, $4.33 \%$ was being used above its capacity, according to the Brazilian Agricultural Aptitude System. The technique used was essential to monitoring areas of land-use considered inappropriate, especially in Permanent Preservation Areas. Thereby, due to application efficiency, it was possible assessing the adequacy of land-use which could sever for make decisions in order to sustainability.

The image classification technique by the MAXVER algorithm for elaborating land-use and occupation maps demonstrated a satisfactory efficiency for this work. The field validation of maps allowed assessing quantitatively such results. As an outcome, land-use, and occupation classification in 2019 was considered excellent (Kappa 0.81), which predominated agriculture, with 50.38\%. 
Analyses in time and space domains combined with other sensors can assist in monitoring land-use for environmental preservation or exploitation for futures investigations in worldwide, considering the sustainable development.

\section{Acknowledgments}

The first author thanks the second author, Marilusa PC Lacerda, for studies advisory and contributions; to Neyara MC Barbosa for help with language reviewing; to Manuel P Oliveira Jr. for technical supporting; and not least, the first author would like to thank also to anonymous reviewers in advance. Also, to the Faculty of Agronomy and Veterinary Medicine - FAV from the University of Brasília - UnB for financial support; and to Laboratory of Geoprocessing and Pedomorphogeology - GeoPed FAV/UnB for the structure provided.

Authors' contributions: JJN - Conceptualization, methodology applying, map validation, writing-original draft preparation, writing-review and editing; MPL - methodology applying, writing-review and editing, supervision.

Ethical approval and other licenses: Not applicable.

Data availability: Quantitative data and shp files are available in the internal database of the Geoprocessing and Pedomorphogeology laboratory (Geoped) from Faculty of Agronomy and Veterinary Medicine - University of Brasília (FAV/UnB) and they can be accessed by request to the authors through electronic mail (geoped.unb@gmail.com). This paper was extracted from a research project performed by the first author during his master's degree, whose dissertation theme was " Digital soil mapping of the Ribeirão Extrema watershed, Distrito Federal, from multitemporal ASTER images and spectral library " available in https://repositorio.unb.br/handle/10482/23146.

Funding Sources: This work was funded by CAPES - Coordenação de Aperfeiçoamento de Pessoal do Ensino Superior (Coordination for Improvement of Higher Education Personal) and CNPq - Conselho Nacional de Desenvolvimento Científico e Tecnológico (National Council for Scientific and Technological Development) and University of Brasília UnB.

Conflict of Interests: The authors declare no conflict of interest.

\section{References}

Almeida RA, Santos LV, Pinto DBF, Ferraz CML. 2020. Temporal analysis of soil occupation in mucuri watershed between 1989 and 2015. Revista engenharia na agricultura - reveng, 28:58-68. https://doi.org/10.13083/reveng.v28i.8474

Borràs J, Delegido J, Pezzola A, Pereira M, Morassi G, Camps-Valls G. 2017. Clasificación de usos del suelo a partir de imágenes Sentinel-2. Revista de Teledetección. 48:55-66. https://doi.org/10.4995/raet.2017.7133

Brasil. Lei n. 12.651, de 25 de maio de 2012. Novo Código Floresetal. Diário Oficial da União, Brasília, DF, Ano CXLIX, n. 102, 28 maio 2012. Seção 1, p.1. https://legislacao.presidencia.gov.br/ atos $/$ ?tipo $=$ LEI\&numero $=12651 \&$ ano $=2012 \&$ ato $=$ a 48 QTVU1kMVpWT59b.

Castro KB, Lima LAS. 2020. Atlas do Distrito Federal. Companhia do Desenvolvimento do Planalto Central CODEPLAN: Brasília, Distrito Federal, Brasil. Volume III. 462 p. http://www.codeplan.df.gov.br/atlas-do-distrito-federal-2020/

Congalton RG, Green K. 2013. Assessing the Accuracy of Remotely Sensed Data Principles and Practices (2nd ed.). CRC Press: Boca Raton, FL, USA. 225 p.

Federal District. 1991. Cartas Planialtimétricas em Formato Vetorial, na escala 1:25.000 e 10.000, Sistema Cartografico do Distrito Federal - SICAD, com informações sobre sistema viáribeirão, hidrografia, hipsometria e áreas urbanas. CODEPLAN - Companhia de Planejamento do Distrito Federal. Brasília, DF. 
ESA - European Space Agency. 2015. Sentinel-2 User Handbook. ESA Standard Document. Rev. 2 European Union. https://sentinels.copernicus.eu/web/sentinel/missions/sentinel-2

ESRI INC. - Environmental Systems Research Institute Inc. 2015. ArcGIS. Professional GIS for the desktop Manual, v. 10.3.1. https://desktop.arcgis.com/en/arcmap/10.3/get-started/quick-start-guides/arcgis-desktop-quick-start-guide. htm

EXELIS INC. 2018. Manual ENVI software, version 5.3. Boulder, Colorado: Exelis Visual Information Solutions, USA. 1272 p. http://www.harrisgeospatial.com/portals/0/pdfs/envi/ENVI_User_Guide.pdf.

Freitas FG, Gomes IA, Ferreira RC, Antonello LL. 1978. Levantamento de reconhecimento dos solos do Distrito Federal. Embrapa - Empresa Brasileira de Pesquisa Agropecuária. Serviço Nacional de Levantamento e Conservação de Solos. Rio de Janeiro, RJ: Embrapa-SNLCS, 220 p. https://www.infoteca.cnptia.embrapa.br/infoteca/bitstream/ doc/335824/2/Mapa-de-aptidao-agricola-dos-solos-do-Distrito-Federal-1978.pdf

Freitas LE, Neves SMAS, Nunes MCM, Serafim ME, Paula DG. 2017. Aptidão agrícola das terras e usos conflitantes nas áreas de preservação permanente da Bacia Ribeirão Jacobina em Cáceres/MT, Brasil. Geografia, Rio Claro, v. 42, n. 3, Especial - GeoPantanal 6:41-56. http://www.periodicos.rc.biblioteca.unesp.br/index.php/ageteo/article/ view/13088/8413.

Jensen JR. 2009. Sensoriamento Remoto do Ambiente: Uma Perspectiva em Recursos Terrestres. Tradução português. 2 Ed. Parentese Editora. SJC. SP, 598p.

Kobayashi N, Tani H, Wang X, Sonobe R. 2019. Crop classification using spectral indices derived from Sentinel-2A imagery. Journal of Information and Telecommunication, 4(1):67-90. https://doi.org/10.1080/24751839.2019.1694765

Lago WNM, Lacerda MPC, Neumann, MRB, Borges TD. 2012. Ocupação e adequação do uso das terras na microbacia do Ribeirão Extrema, Distrito Federal - Parte II, Revista Brasileira de Engenharia Agrícola e Ambiental 16(3):289296, https://doi.org/10.1590/S1415-43662012000300009

Leopoldo NCM, Costa TGA, Iwata BF, Toledo CE. 2020. Vulnerabilidade ambiental do Parque Nacional das Nascentes do Rio Parnaíba - PNNRP. Gaia Scientia, 14(1):33-42. https://doi.org/10.22478/ufpb.1981-1268.2020v14n1.46029

Mylona E, Daskalopoulou V, Sykioti O, Koutroumbas K, Rontogiannis A. 2018. Classification of Sentinel-2 Images Utilizing Abundance Representation. Proceedings, 2(7):328. https://doi.org/10.3390/ecrs-2-05141

Nguyen HTT, Doan TM, Tomppo E, Mcroberts RE. 2020. Land Use/Land Cover Mapping Using Multitemporal Sentinel-2 Imagery and Four Classification Methods - A Case Study from Dak Nong, Vietnam. Remote Sensing, 12(9):1367. https:// doi.org/10.3390/rs12091367

Novaes Pinto M. 1994. Caracterização geomorfológica do Distrito Federal. In: Novaes Pinto M. (Org.). Cerrado: caracterização, ocupação e perspectivas. Brasília, DF: Universidade de Brasília/SEMATEC, p. 285-344.

Novais JJ, Moura CFO, Souza SR, Torres CJF. 2016. Mapeamento do uso e ocupação do solo na bacia do Rio Verruga BA. Enciclopédia Biosfera, 13(23)720-730. https://doi.org/10.18677/Enciclopedia_Biosfera_2016_063.

Radoux J, Chomé G, Jacques D, Waldner F, Bellemans N, Matton N, Defourny P. 2016. Sentinel-2’s Potential for Sub-Pixel Landscape Feature Detection. Remote Sensing, 8(6):488. https://doi.org/10.3390/rs8060488.

Ramalho Filho A, Beek KJ. 1995. Sistema de Aptidão Agrícola das Terras. $3^{a}$ ed. Revisada, Rio de Janeiro: Embrapa CNPS, 65 p.

Sano EE; Rodrigues AA; Martins ES; Bettiol GM; Bustamante MMC; Bezerra AS; Couto Jr. AF; Vasconcelos V; Schüler J; Bolfe EL. 2019. Cerrado ecoregions: A spatial framework to assess and prioritize Brazilian savanna environmental diversity for conservation. Journal Environmental Management. 232:818-828. https://doi.org/10.1016/j.jenvman.2018.11.108. 
Santos HG, Jacomine PKT, Anjos LHC, Oliveira VA, Lumbreras JF, Coelho MR, Almeida JA, Araújo Filho JC, Oliveira JB, Cunha TJF. 2018. Sistema Brasileiro de Classificação de Solos. Embrapa Solos: Rio de Janeiro, RJ, Brazil. 631 p. https://ainfo.cnptia.embrapa.br/digital/bitstream/item/199517/1/SiBCS-2018-ISBN-9788570358004.pdf.

Silva CVT, Ribeiro Filho JC, Silva PCM, Lemos Filho LCA, Brasil, JB. 2017. Caracterização morfométrica, uso e ocupação de uma bacia hidrográfica. Revista engenharia na agricultura - reveng. 25(5):436-444. https://doi.org/10.13083/reveng. v25i5.828

Souza V, Galvani E, Souza ML. 2015. Determinação e Adequação da Capacidade de Uso da Terra em Bacia Hidrográfica por Meio de Sistematização Metodológica no SIG SPRING. Geografia. 24(1):55-69. http://www.uel.br/revistas/uel/ index.php/geografia/article/view/19345.

United Nations. 1987. Report of the World Commission on Environment and Development: Our Common Future. Gro Harlem Brundtland Oslo, 20 March 1987.30 p. https://www.un.org/ga/search/view_doc.asp?symbol=A/42/427\&Lang=E

Wang B, Jia K, Liang S, Xie X, Wei X, Zhao X, Zhang X. 2018. Assessment of Sentinel-2 MSI Spectral Band Reflectances for Estimating Fractional Vegetation Cover. Remote Sensing, 10(12):1927. https://doi.org/10.3390/rs10121927. 